Michał A. Michalski

Adam Mickiewicz University in Poznań

Faculty of Social Sciences

Institute of Cultural Studies

e-mail: mmichal@amu.edu.pl

\title{
The ageing of society in the context of dominant assumptions of contemporary economics and culture*
}

\begin{abstract}
Current demographic trends indicate that the process of ageing is more and more advanced in Western societies. While the available literature addressing this issue concentrates most often on developing effective tools for socio-economic policy, this paper aims at exploring the dominating assumptions of economics and culture to find how they may influence the demographic process that was mentioned. The purpose of the analysis undertaken here is to verify the thesis which claims that basic anthropological assumptions present in neoclassical economics and modern culture somehow ignore or underestimate such essential aspects of human life as old age and the helplessness or weakness connected with it.

The conclusions of the paper indicate that there is a need for intergenerational balance within society, which, e.g., facilitates socio-economic development. Some of the most important factors influencing this may or may not be present within the economic theory and culture it is based on. It means that without the adequate vision of man and the phases of human life, the process of building a mentally healthy and vibrant society where everyone has his or her place is hardly possible.
\end{abstract}

Keywords: ageing, pensioners, sociodemographic shifts, cultural context, economic thought

JEL Classification: J11, J14

\footnotetext{
* The article is an updated version of the paper published in Polish in the Annales. Ethics in Economic Life, 20(3), 21-36.
} 


\section{Introduction}

The goal of this article is to analyse the role that economic theory-and, more broadly, culture - plays in perceiving social phenomena and making decisions that pertain to them. This work focuses on the importance of theoretical assumptions regarding human beings - especially old age - for the functioning of socioeconomic order. Undertaking such an analysis seems even more interesting and significant if we consider that the issue of ageing communities is becoming more and more topical and deserves thorough investigation.

We are going to analyse, then, to what extent the claims within the dominant economic theory-treated here as one element of culture-support the proper understanding of ongoing processes and how they influence an effective solving of problems that arise along with it.

In the available literature, the connections between the ageing of society and socio-economic policies are the domain of interest of scholars in areas such as demographics, economics, or sociology. Therefore, the main perspective I have adopted will refer to cultural studies, which provides a broader cognitive framework for reflecting upon the concept of old age and its status in economic theory. When going through the growing body of research and analyses on population ageing, we should note that by focusing on providing solutions from the field of socio-economic policy they deal less often with the question of assumed anthropological adequacy, i.e., the way they perceive people as subjects of social life. This work is an attempt to fill this gap.

Therefore, I present here a hypothesis that proper understanding and reacting to the process of society ageing, also adequately managing it, requires, on the one hand, extending or even going beyond the perspective of neoclassical economics and the homo oeconomicus model it utilises. On the other hand, it calls for a critical analysis of cultural claims that facilitate the rise and solidification of the age structure that is undesired from the viewpoint of socio-economic development.

\section{Old age as a natural stage of human life and a component of social order}

When analysing old age, we should first define how we understand the term, which, after all, refers to universal human experience.

It should be noted that old age in itself is not a problem, because it is an objective process that is an integral part of human life. However, it is connected with certain difficulties - both for the individuals and for society as a whole. And so we speak not only of ageing individuals but also of an ageing population (cf. Jurek, 2012 , p. 17). This results in old age becoming - especially in recent years-an important challenge for socio-economic policy but also, and in a way because of it, a popular research topic (cf. Golinowska, 2008, p. 27). 
Returning to the definition of old age, we can see it is an uneasy task, which is evidenced by the subject literature. Lukasz Jurek (2012, p. 19) writes that so far there has been no univocality on the matter of a universally accepted threshold of when old age begins. He notes, however, that most scholars assume that the proper criterion for qualifying anybody as old is between 60 and 65 years of age.

A different author writes about three approaches to defining old age. The first of them, described as subjective, refers to how an individual evaluates their activity on the job market and their state of health. The second stance, called the functional approach, uses objective data such as employment status, entitlement to social benefits or mental condition. The third approach uses the criterion of age, which entitles individuals to a pension or other benefits resulting from the number of years they have lived (cf. Zaidi, 2008, p. 28). To complete this list, we should consider defining old age as the stage in our lives when our weakness and dependence can be seen much more clearly than in our productive age. In such a definition we avoid, on the one hand, purely formal or numerical limitations and, on the other, the subjectivity of a given individual's perspective. ${ }^{1}$

From among the presented approaches we shall adopt here the last presented understanding of what old age is because it presents us with the most objective perspective on the topic. At the same time, I do realise that it is not perfect and that other approaches can be justified and useful. ${ }^{2}$

When it comes to understanding old age, we should explain a few matters. First, old age is here recognised as a natural stage of human life, which means that it is an indispensable consequence of living (although it does not always occur if death comes earlier) and thus an inescapable perspective in human existence. As such, it should be seen as an important element related to the functioning of the socio-economic order. Second, old age - not unlike childhood-clearly presents a fundamental characteristic of human relations that cannot be properly described in purely economic terms. This is because it shows that in a society there always will be a space of asymmetric relations - ones in which there is no equality in the contributions or potential of its participants-which are fundamentally different from the symmetrical relations of market partners (cf. Morse, 2001, p. 25). Chantal Delsol (2006, p. 142) writes about how the latter outnumber the former in human life:

Avoiding the inequality between giver and recipient breaks the relationship between them. [...] Equality is maintained, but at the cost of a broken relationship. In the realm of human bonds only genuine friendship implies equality. All other relationships are unequal, that is, they entail giving that sometimes goes unreciprocated.

\footnotetext{
${ }^{1}$ In a way this definition of old age is reflected in the social benefits system, where, on the one hand, we have pensions granted according to age or number of years in work (which can be understood as exhaustion of energy necessary for professional activity), on the other we have disability pensions granted in special circumstances to people (regardless of their age) who for some reason suffer from weakness or lack of independence.

${ }^{2}$ Jan Szczepański (1980, pp. 228-240) interestingly writes about problems with defining old age.
} 
This means, in turn, that economics as a discipline specialising in interactions of a symmetrical nature cannot explain the character of a wide range of phenomena and practices that are not commercial in character. ${ }^{3}$ The term "non-economic" was not used here on purpose so that we do not associate with economics only such practices that pertain to the money-goods exchange governed by market rules. As a result, we can still see areas associated with, say, running a household, where we can recognise many acts of an economic nature since they aim to satisfy specific human needs with the available means and material resources.

It seems, therefore, that by directing our attention to the phenomenon of old age - and the accompanying sense of human helplessness - we gain a chance to restore a real shape to the subject of socio-economic processes, which, although officially called human, apparently lost its human form and attributes. This is what we are going to investigate.

\section{Economics and old age-who is the "protagonist" of neoclassical economic theory and what is his logic?}

Now, we would like to look at the subject of economic practices and do so in a way that economics itself sees them. First of all, we intend to prove that the model of human beings most often adopted in economic sciences ${ }^{4}$ lacks fundamental characteristics that connect them with the phenomenon of old age. It is worth analysing the origin of the "economic man" who-despite being criticised in recent years - still seems to be a focal point in economic thought. ${ }^{5}$ Janusz R. Sobczyk (2008, p. 140) writes about the beginning of the concept of homo oeconomicus:

closest to its cradle stood those responsible for this deceitful conceptual juggling: A. Smith (classical economics), J. Bentham (utilitarianism), J. Mill and J.S. Mill; behind their backs was the entire tradition of English philosophy: empiricism (F. Bacon), mechanistic ontology (I. Newton), sensualistic epistemology (J. Locke), associative psychology (D. Hume) and naturalistic ethics of egoism and hedonism (T. Hobbes). In this way, the newly created concept, an intellectual product of a typically British mentality - still in the form of a nameless idea, or, if you will, a silent assumption, became the matrix of burgher ideas on the nature of man, the market and economy.

\footnotetext{
${ }^{3}$ We should mention here the contribution made by, among others, Gary S. Becker, who by applying economic tools to behaviour not usually associated with this discipline, to an extent was able to draw our attention to matters not very well analysed before, such as the importance of families for the functioning of the economy.

${ }^{4}$ Primarily, it pertains to neoclassical economy, which more or less since the 1970s has dominated economic theory and still seems to be its mainstream (cf. Stankiewicz, 1998, pp. 390-391, 416-423).

${ }^{5}$ We should, of course, mention the concept of the "sociological man", which is a mostly successful attempt to elaborate and develop the way we think of human beings. Although it became quite popular in sociology, it seems that in economics the dominant way of looking at people is through the lens of the "economic man" paradigm (cf. Morawski, 2001, p. 33).
} 
The description above seems important insofar that it shows which philosophical concepts, including ethical and anthropological, can be found in the "character" of homo oeconomicus. Frank Knight defines the term further (1951, p. 282 as cited in Chmielecki, 1999, p. 260):

economic man is not a "social being", economic individualism rules out society in the properly human meaning of the term. Economic relations are presented here as impersonal. Social structure, as seen by the economic theory, is a number of Robinsons interacting with each other solely through the market.

As a matter of fact - as we have observed - the experience of fragility, defencelessness and helplessness is an immanent part (although to a varied extent) of human life and it is not limited to just childhood or old age. It means, then, that its asymmetrical character should be treated as a basic trait of the human condition. It does not mean, however, that only asymmetrical relations should be claimed to be truly human.

In order to present it properly, it is worth showing the issue in the form of two logics: of giving and contract. The first one, according to Chantal Delsol (2006, pp. 144-145), in a way conditions the creation of society. She writes that:

every human relationship begins with a need that one is willing to see filled. This is not a matter of finding a permanent solution for an abnormal or unjust situtaion with the goal of achieving self-sufficiency or "normality”. The first condition of a "society" is the acknowledgment of our constitutive insufficiency. I cannot build relationships if I do not recognize my won need, conceived not as an exceptional circumstane or an injustice awaiting redress, but as a substantial quality. This sense fo finiteness is what creates a common world and at the same time gives it meaning.

The quote above might look very serious, but maybe in it we can find an explanation for what is in various works called the erosion of social bonds (cf. e.g. Bellah, Madsen, Sullivan, Swidler \& Tipton, 1996, p. XI.), which can be facilitated by the proliferation of symmetrical relations and the logic of contract that it entails.

As far as these two logics go, it seems that nowadays the idea that the logic of contract is more effective and useful in everyday life seems to be the dominant one. In such a perspective we can see an assumption that these two logics are somewhat in opposition to each other. In reality, however, they are complementary elements, not alternatives, in the same way as, e.g., the sphere of family life should not be treated as the opposite of the sphere of market exchange. It is well understood by Luigino Bruni (2008, p. X), who writes that "[...] contract (selfinterested exchange) and mutual gift are surely two different forms of reciprocity, but these are both forms of reciprocity that are essential in a good society."

Certainly, the presence of the two logics discussed here means that social interactions cannot be reduced to simply "some providing for others" or just calculations based on the principles of equivalence. Clearly, choosing one of these paths 
might seem a simple solution, but in truth, it is a trap. Despite that, it seems that historical records abound in examples of such social arrangements. While cases of utopian attempts to make everything free are evidently irrational and ineffective, the illusion that social order can be based solely on the logic of contract further gains supporters. In this perspective, it seems especially appealing to accept the argument according to which a relatively simple market mechanism — as a leading example of contractual logic - is a sure and the easiest solution of problems within society. However, we should remember here about the idea by Rocco Buttiglione (2005, p. 349), who writes that "[...] a contract [...] is possible only in a situation where there exists a relative balance of power." As a consequence, we can say that in a situation of imbalance we first need a gift, thanks to which it will be possible to introduce contractual logic. In a similar vein, we can understand the claim by George Gilder, who writes that "capitalism starts with giving" (Gilder, 1993, p. 21). It can be seen very clearly in the process of human development; before people become fully mature and independent members of a society, capable of playing various roles in it, including, e.g., professional roles, people have to get support. This can come in the form of means for living and growing in the biological sense, and competencies and skills in the process of socialisation, among others.

The issues presented above prove that economics is insufficient for explaining how societies work - even the so-called industrial or consumption societies, where the economic dimension seems to play a crucial role. This is so because it fails to provide adequate anthropology that could grasp human experience in its entirety. In this same context, the problem discussed here can be reduced to the absence of asymmetrical relations in the economic perspective, because these relations are no less important for society; indeed, in many aspects, they should be considered more so.

Returning to the way humans are perceived by the dominant economic theory, we should say a few words about how they are characterised. A trait that can be seen very clearly - which can, of course, be associated with its "model nature" - is their abstract, in a sense, ahumanist character. It is evidenced by their asexuality, which means that a dimension as important as sexuality is ignored, and with it, various significant tasks and social roles, such as parenthood. Together with it also disappear basic relations and generational dependencies, which we cannot omit while discussing the question of old age. From it stems a certain atemporality of the economic man - he does not belong to any generation, does not age, is not engaged in any human relationships, even as basic as being a child to their parents. His ahumanist character means that they also cannot change, which leads to the conclusion that he is not affected by the passage of time, which is connected with the inescapable nature of the processes and changes that pertain to old age. 
We are going to try and show these paradoxes by juxtaposing family and market relations as spheres depicting the differences between the two discussed earlier logics and the ways of treating other people that are peculiar to each of them. It can be seen in Table $1 .{ }^{6}$

Table 1. Family Relations vs Market Relations

\begin{tabular}{lcc}
\hline & Family & Market \\
\hline The dominant characteristic of the relation & Personal & Material \\
\hline The temporal horizon of the relation & Long-term relations & Short-term relations \\
\hline The relationship of the parties & Asymmetrical & Symmetrical \\
\hline Gratification & $\begin{array}{c}\text { Postponed or no } \\
\text { gratification }\end{array}$ & $\begin{array}{c}\text { Immediate/less often } \\
\text { postponed }\end{array}$ \\
\hline The dominant logic & Gift & Contract \\
\hline The final perspective & Personal & Individual \\
\hline
\end{tabular}

Looking at the comparison above, we should ask an apparently trivial question of whether economic man, crafted primarily for market relations, can cope on his own in old age. It seems obvious that he will not.

Despite it being so evident, we still do not fully realise it. Even if we witness in economics not only discussions and proposals of changes but also specific ideas for changing our understanding of how humans manage their lives in society, it should be noted that many administrative and legal economic solutions reflect a paradigm in which individuals are not unlike Robinson Crusoe in their actions. The problem is that nowadays - in the face of demographic shifts - they grow old, and hence the question of whether they can cope as well as they have done so far is becoming more and more urgent, and we do not even know if we can realistically expect that to happen.

\section{Cultural status of old age}

In the light of the analyses presented above regarding people seen as subjects of socio-economic practices and processes, it is worth asking why this anthropological model dominates in our understanding of the world, not only in economic terms. Perhaps it could be more useful if it was treated purely as a model. Maybe it is so widespread because it was assumed that, firstly, it would always be used with the awareness that it is just an anthropological reduction, and secondly, that such an inadequate simplification would have no serious ideological consequences (cf. Nowak, 2007, pp. 28-29).

In order to resolve these questions, it seems necessary-and it has already been done to a large extent - to analyse the role that economics plays as a theory explaining human actions. It has been done so primarily in the economic sphere

\footnotetext{
${ }^{6}$ It is important to remember, however, that the market here is not treated as a synonym for the whole economy, which is a much wider domain.
} 
but also-for some time now - in other domains, which it has brought its apparatus to (to the irritation of some) (cf. Lompart, 2007). However, in order to fully grasp the importance of economic theories, we should begin with a much broader perspective of culture. We define it here as an immaterial sphere consisting of symbols, values and ideals (cf. Krzysztofek, 1991, p. 17). Like Samuel P. Huntington, we can claim that "[...] we define culture in purely subjective terms as the values, attitudes, beliefs, orientations and underlying assumptions prevalent among people in a society" $(2000$, p. XV).

It turns out that adopting a cultural framework is necessary because economics is not an autonomous discipline in the sense that it is not independent of the currently dominating paradigm in culture. It is worth mentioning a fragment of David Throsby's (2010, p. 22) analysis, where he writes:

The formal precision of modern economics, with its theoretical abstraction, its mathematical analytics and its reliance on disinterested scientific method in testing hypotheses about how economic systems behave, might suggest that economics as a discipline does not have a cultural context, that it operates within a world that is conditioned by, nor conditional upon, any cultural phenomena. But just as the radical critique of contemporary economics has argued that the sort of economics described above cannot be value-free, so also can it be suggested that economics as an intellectual endeavour cannot be culture-free.

I will concentrate on culture, firstly because specific theories, including economic ones, reflect in their assumptions cultural claims. Secondly, by referring to the anthropology of economic man, we have shown the way reality is perceived that currently dominates in culture and is reflected in economics.

Therefore, I assume that the problems analysed here-with special emphasis on the issue of old age - are rooted in culture, which has changed radically in the past few decades. In the context we are interested in, we will devote special attention to aspects of identity related to age and intergenerational relations.

Analysing current socio-cultural reality, we might get the impression that Manuel Castells described as social arrhythmia. It is - especially if contrasted with the past - a phenomenon that forces us to think and search for adequate models for action. Castells (2007, p. 444; cf. Berger \& Luckmann, 2010, pp. 77-79) writes:

The current organisational, technological and cultural events, characteristic of a new, emerging society, heavily undermine this ordered cycle of life, without replacing it with any alternative sequence. I suggest a hypothesis that network society is characterised by a collapse of rhythms, both biological and social, related to the concept of the cycle of life.

A matter discussed by Castells, especially important for the analysis at hand, is the collapse of rhythms that pertain to the life of an individual but also affect their personal relationships, also in the intergenerational perspective. It means that the traditional and natural cycle of life, resulting from objective biological factors, is becoming more and more a subject to individual manipulation. It is surely facili- 
tated by various scientific and technological achievements, which, although providing an illusion of control over inescapable physiological processes or hope for slowing them down, cannot stop nor reverse them.

When it comes to the direction of this struggle, the desired effect is clearly to prolong or even preserve youth, which in a way is connected with the perennial human desire for immortality and perfection. However, a particular characteristic of our era is that people have at their disposal a wide range of means for attempting to realise such aspirations.

We live in an era that, according to Robert J. Samuelson, is characterised by agelessness, which can be defined as abstracting from age or ignoring it. The author, quoted by Benjamin R. Barber (2003 as cited in Barber, 2009, pp. 12-13) in the book Consumed, states:

We live in an age when people want to behave their age less and less. The younger (or many of them) want to be older, the older (or many of them) want to be younger. We have gradually destroyed the traditional stages of the cycle of life by shortening childhood, after which come several not very well-defined intermediate stages. Youth [...] starts before puberty and for some lasts until the end of life $[\ldots]$ Denying one's age is a common practice.

When analysing this issue, Barber refers to the concepts of infantilisation and adultisation, which clearly show the consequences of upsetting the cycle of life connected with the social arrhythmia mentioned above. On the one hand, these terms mean a tendency to treat adults like children, and on the other, to behave towards children as if they were already independent and mature. An area where it is especially evident is the market, where products and services once reserved for specific age categories are addressed to those outside of the target age groups. From the economic perspective, it is certainly supposed to result in broadening the group of consumers and, as a consequence, increase the market share and profits. From a cultural perspective, however, it leads to homogenisation and the disappearance of distinctions fundamental to the functioning of social order. As a result, objective - and in a way universal-generational differences and the roles and duties they entail are replaced by an individually and purely subjectively shaped individual identity. In consequence, age, which to a larger extent used to define one's place in the age structure and specify one's social role, is more often perceived in the current cultural context as a voluntary element that one is free to treat according to subjective preferences.

It is one of the consequences of the power that individualism has been given in our contemporary culture. It weakens the connection that an individual has with basic groups (such as their family) and other communities, including their societies. Absolutising the individual dimension is, however, a fake promise and, paradoxically, as Ulrich Beck writes, the individual " $[\ldots]$ is losing importance and is simultaneously given an illusory status of the world's co-maker" (Beck, 2002, p. 205). It means a specific crisis of that which is common, which is an element of the world of life and the community of values and ideals connected with it, which are elements of culture. As a consequence, the place of a universally perceived, 
created and experienced reality is taken by a multitude of alternative worlds, whose reality can be contested. It is partially confirmed by the popularity of mass media, especially of programs offering access to unreal worlds. Alvin and Heidi Toffler (2007, p. 14) wrote:

[...] To escape — or at least forget—what appears like chaos, millions turn to television, where "reality TV" fakes reality. Thousands form "flash mobs" and gather to beat one another with pillows. Elsewhere, players of online games pay thousands of dollars in real money for nonexistent, virtual swords that their virtual selves can use to win virtual castles or maidens. Irreality spreads.

So, we are dealing with a culture that in various ways tries to distance itself from reality. This leads us to the conclusion that we are facing a widespread and powerful cult of youth because youth is what we typically associate with carelessness, fun, and indifference to objective conditions and limitations. And these are the areas that our contemporary culture likes so much.

The protagonists of the thus characterised contemporaneity are young, healthy, beautiful, intelligent, rich individuals. They are not old, ill, poor or weak. This allows us to describe the currently dominating way of perceiving and valuing the world as a culture of the strong, which — in the ethical dimension-bears the hallmarks of social Darwinism. This problem is presented in an interesting way by Edwin Black in his book War Against the Weak (2004). He shows how the events of the $20^{\text {th }}$ century, especially the genocide of World War II, are ideologically rooted in $19^{\text {th }}$-century eugenics and last in some form in the $21^{\text {st }}$ century, when the value of human life becomes a thing of a purely individual decision or a matter that the majority can decide on. Black (2004, p. 47) writes:

Now social planners were rallying around the notion that in the struggle to survive in a harsh world, many humans were not only less worthy, many were actually destined to wither away as a rite of progress. Supporting the weak and the needy was, in essence, an unnatural act.

Our contemporary culture is, in fact, regressive because it takes humans back to nature, where strength and adaptability are fundamental regulators. It results in making human being a specimen and no longer a person.

It is well illustrated by the situation of children in general, especially unborn children. Buttiglione (2005, p. 349) writes about this in the context of logics presented above:

we clearly see here a model of a subject that is completely devoid of power and, therefore, excluded from the contract. The question of legalising abortionregardless of its objective moral gravity-is also a touchstone of the anthropology and self-awareness of the nation, it is a touchstone of the quality of justice that the nation intends to rest their existence on [...] The same goes for the old. An old person gradually loses strength and thus - according to the concept of 
conventional justice- - loses rights. In the final stage of their lives, they are completely devoid of strength as well as rights. A sick and disabled person is in a similar situation.

These remarks allow us to claim that the current cultural paradigm affects the status of the old in society and the way we perceive old age in general.

\section{Conclusion-what future does an ageing society have?}

In conclusion, we can say that the fate and future of ageing societies will be mainly influenced by cultural premises, including, among others, anthropological, ethical and those included in economic theories, and to a lesser extent by currently possessed material resources. ${ }^{7}$ It means that the theoretical background is crucial. It seems especially important in the context of the pragmatic lifestyle which nowadays is widespread and popular.

To a large extent, this seems to be the way in which current welfare mechanisms work. They are characterised-despite their obvious differences-by a conviction that providing basic means for existence is the key to social order and progress. Unfortunately, it is not the case. When it comes to the topic at hand, welfare states seem too centralised to address the problem of old age effectively. This is because old age is a complex and unpredictable matter to manage within a state's macrostructures, which do not handle non-standard and non-routine circumstances well.

Another problem of the welfare state is the influence it has on the status of care work - indispensable in the case of children and the elderly-which is becoming depreciated. This is because the state, by "taking over" ${ }^{8}$ the task of providing care and social safety, gives the false impression that the natural connection between how families work, performing procreative, socialising or care functions, and generating resources for social security has weakened. As a result, the general public becomes convinced that taking on family roles and duties, especially those related to care and upbringing, is not necessary from the perspective of how the state and society operate. Because of this and the fact that caring and fostering are demanding and, unfortunately, hardly ever paid, they have a low cultural status. This, in turn, sends an important message to generations entering adulthood and leads to this kind of work not being very popular, which aggravates the demographic and economic crisis of many welfare states.

We are facing a situation where the dominant shape-especially in Western civilisation - of culture emphasises individuality and subjective autonomy on the one hand, and, on the other, strengthens the passivity of its citizens, who assume

\footnotetext{
${ }^{7}$ An example of this can be the issue of effectiveness of state financial incentives for increasing women's fertility rate in various countries.

${ }^{8}$ The quotation marks used here mean that the state does not have "its own" money, but it finances its enterprises using resources created by its citizens, who have to a large extent become mature members of the society thanks to free care and fostering work done in families.
} 
that the state will take care of them in every circumstance, including their old age. As far as its condition and competitiveness go, it is becoming clear that the West is giving way to other civilisations. An important consequence of this is the ageing of the society. Obviously, steps are taken to maintain the socio-economic order, but their perspective is rather short-term.

In such circumstances, some countries have for years now supplied their population with immigrants, who, in turn, were able to support the basic "life functions" of society. However, such a strategy results in a more or less fundamental cultural transformation, which shows more and more clearly how barren a culture is that does not respect the fact that for the intergenerational contract to work well we need balance between generations, which helps society develop and engage and utilise the potential of each generation in the most effective and adequate manner.

An alternative, which is sometimes treated as an inescapable perspective and, to some extent, as an attempt to adapt to our current demographic trends, is the greying economy. However, it is an idea for a short-term adjustment rather than a comprehensive and adequate solution to the growing problem. Of course, we can emphasise the necessity to meet the demand for goods and services by the elderly, but from the viewpoint of serious long-term social policy, we should ask what should be done in the context of a society that is seriously shrinking.

Therefore, we should consider whether building a greying society-without analysing thoroughly the cultural context we mentioned above-would not be just an attempt to make the elderly as strong and fit as possible, rather than carefully recognising and accepting the uniqueness and meaning of old age in the social order. To expect that in the new context all elderly people will be able to adjust to new challenges, such as longer professional activity, is far from rational.

So, it seems justified to say that the greying economy is not the right solution to the problem of the rising demand for specific goods and services for the elderly, although, due to the ageing of society, such an economic model will, in some way, emerge in the short term. The very concept itself cannot offer any appropriate remedy because it would need an appropriate social philosophy. Such a system would have to be rooted in a culture that would respect the objective characteristics and attributes of human life in the personal dimension, joining and revealing as indispensable and mutually complementary the individual and collective aspects of human existence. Here, we can recall the words of the economist Jennifer Roback Morse (2001, p. 27), who writes:

societies do much better if they face facts rather than ignore them. In particular, political philosophies and their accompanying social philosophies need to address the limits of human power. We are all completely incapacitated in infancy, and even adults at the height of their capacities are far from omnipotent. If philosophies and the societies built around them ignore either of these truths of human helplessness, negative consequences will follow. 
The problems discussed here surely deserve a deeper and more thorough analysis, especially because our work shows, to some extent, how multidimensional and complex they are. It seems that further investigation may be necessary not only to harmonise our current tensions and the challenges they present us with, but also - which seems even more important - to search for such cultural solutions that would facilitate the consistent development of societies. It will be possible only when certain principles are observed, such as the fundamental rules governing human life that show the objective importance and meaning of each stage in human life both in the individual and intergenerational dimension in the context of the entire society.

\section{References}

Barber, B. R. (2009). Skonsumowani. Jak rynek psuje dzieci, infantylizuje dorostych i polyka obywateli. Warszawa: Warszawskie Wydawnictwo Literackie Muza SA.

Beck, U. (2002). Spoleczeństwo ryzyka. W drodze do innej nowoczesności. Warszawa: Wydawnictwo Naukowe Scholar.

Bellah, R. N., Madsen, R., Sullivan, W. M., Swidler, A., \& Tipton, S. M. (1996). Habits of the heart: Individualism and commitment in American life. Berkeley-Los Angeles-London: University of California Press.

Berger, P. L., \& Luckmann, T. (2010). Społeczne tworzenie rzeczywistości (J. Niżnik, Trans.). Warszawa: Wydawnictwo Naukowe PWN.

Black, E. (2004). Wojna przeciw słabym. Eugenika i amerykańska kampania na rzecz stworzenia rasy panów. Warszawa: Warszawskie Wydawnictwo Literackie MUZA SA.

Bruni, L. (2008). Reciprocity, altruism and the civil society. New York: Routledge.

Buttiglione, R. (2005). Etyka wobec historii. Lublin: Towarzystwo Naukowe Katolickiego Uniwersytetu Lubelskiego.

Castells, M. (2007). Społeczeństwo sieci. Warszawa: Wydawnictwo Naukowe PWN.

Chmielecki, A. (1999). Rzeczy i wartości. Humanistyczne podstawy edukacji ekonomicznej. Warszawa: Wydawnictwo Naukowe PWN.

Delsol, Ch. (2006). The unlearned lessons of the twentieth century: An essay on late modernity. Wilmington: ISI Books.

Gilder, G. (1993). Wealth and poverty. San Francisco: ICS Press.

Golinowska, S. (2008). Społeczno-ekonomiczne konsekwencje starzenia się ludności. In J. Kleer (Ed.), Konsekwencje ekonomiczne i społeczne 
starzenia się społeczeństwa. Warszawa: Komitet Prognoz "Polska 2000 plus" przy Prezydium PAN.

Huntington, S. P. (2000). Cultures count. In L. E. Harrison, \& S. P. Huntington (Eds.), Culture matters. How values shape human progress. New York: Basic Books.

Jurek, Ł. (2012). Ekonomia starzejącego się społeczeństwa. Warszawa: Difin.

Knight, F. (1951). The ethics of competition. New York: Augustus M. Kelley.

Krzysztofek, K. (1991). Cywilizacja: dwie optyki. Warszawa: Instytut Kultury.

Lompart, A. (2007). Imperializm ekonomiczny - czy zagraża socjologii? In J. Kochanowicz, S. Mandes, \& M. Marody (Eds.), Kulturowe aspekty transformacji ekonomicznej. Warszawa: Instytut Spraw Publicznych.

Michalski, M. A. (2017). Starzenie się społeczeństwa w kontekście dominujących założeń współczesnej ekonomii i kultury. Annales. Ethics in Economic Life, 20(3), 21-36.

Morawski, W. (2001). Socjologia ekonomiczna. Problemy. Teoria. Empiria. Warszawa: Wydawnictwo Naukowe PWN.

Morse, J. R. (2001). Love \& economics: Why the laissez-faire family doesn't work. Dallas: Spence Publishing Company.

Nowak, S. (2007). Metodologia badań społecznych. Warszawa: Wydawnictwo Naukowe PWN.

Samuelson, R. J. (2003, November, 3). Adventures in agelessness. Newsweek.

Sobczyk, J. R. (2008). Historia naturalna homo oeconomicus - od narodzin po cywilizacyjny kryzys współczesności. In S. Partycki (Ed.), Kultura a rynek. Lublin: Wydawnictwo KUL.

Stankiewicz, W. (1998). Historia myśli ekonomicznej. Warszawa: Polskie Wydawnictwo Ekonomiczne.

Szczepański, J. (1980). Sprawy ludzkie. Warszawa: Czytelnik.

Throsby, D. (2010). Ekonomia i kultura. Warszawa: Narodowe Centrum Kultury.

Toffler, A., Toffler, H. (2007). Rewolucyjne bogactwo. Przezmierowo: Wydawnictwo Kurpisz SA.

Zaidi, A. (2008). Well-being of older people in ageing societies. Aldershot: Ashgate. 